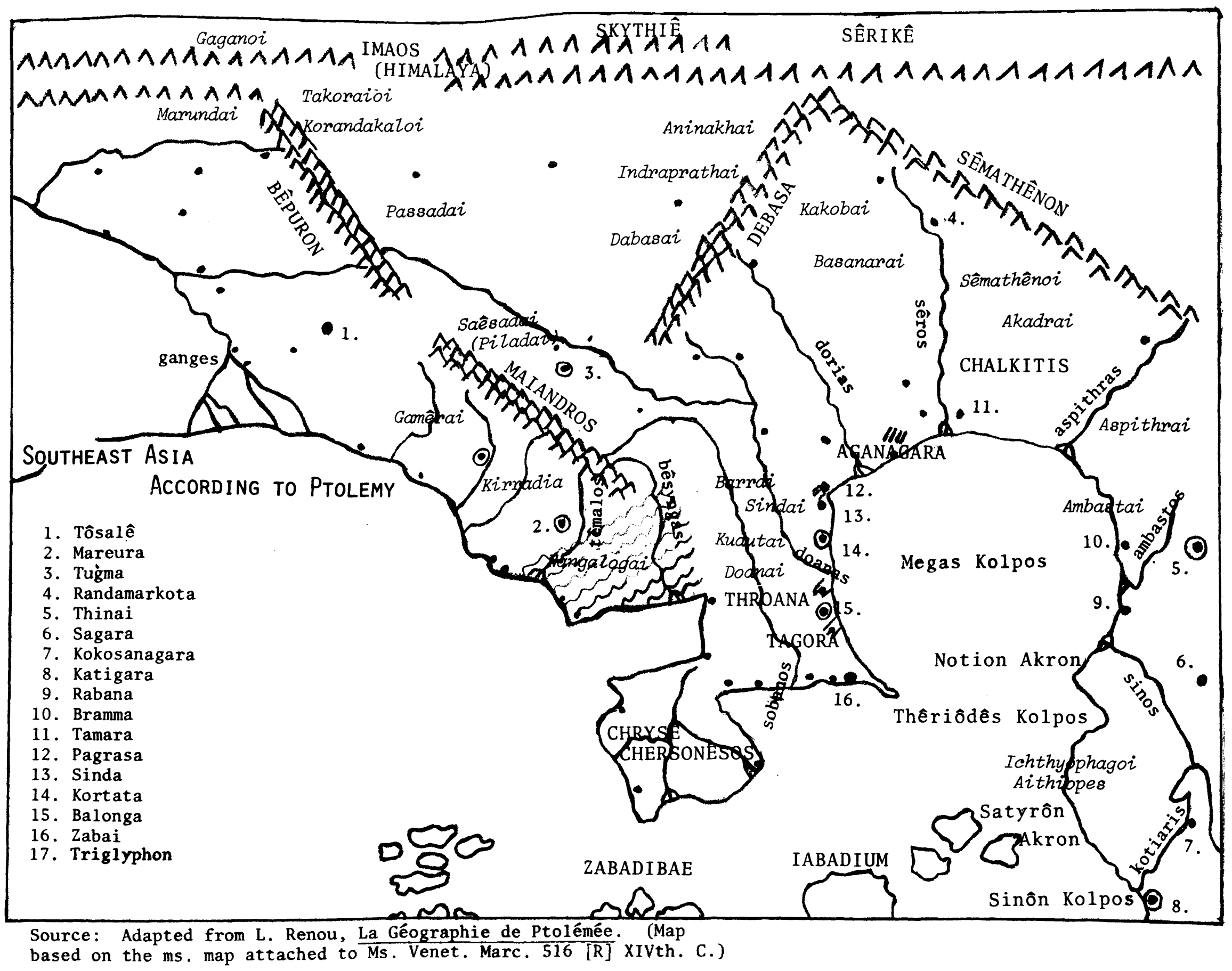




\section{PTOLEMY'S GEOGRAPHY OF MAINLAND SOUTHEAST ASIA AND BORNEO}

W. J. van der Meulen

In "Suvarnadvîpa and the Chrysê Chersonêsos"l we traced Ptolemy's circumnavigation of the Golden Peninsula from Takôla to the Bay of Perimula, and continued the route along the Tembesi and Batanghari rivers until we reached Jambi, Ptolemy's Zabai. From here, according to Ptolemy, the voyagers had to round an unnamed promontory east of Zabai, after which their course turned sharply northwest into the Megas Kolpos or Great Gulf. This gulf has a more or less spherical shape on the Ptolemaean maps, its slightly narrowed opening pointing south. The voyagers evidently worked their way northward along the western shore of this inverted bowl until at the very "bottom" they reached the mouth of the Seros Potamos (Silk River), which formed part of the boundary between India-beyond-the-Ganges and the Region of the Sinai. From there they turned south along the opposite eastern shore until they reached the river Sinos and Notion Akron (Cape Notion), which corresponded with the promontory at the start and thus marked the end of the gulf.

What must really have happened after the voyagers put out to sea from Jambi and what must have been mentioned in the original sources upon which Ptolemy built his Geography, was that they sailed for perhaps two days in an easterly direction and after that changed their course to the northwest. The reason for this is evident. Taking their bearings from Berhala Island (also a popular seamark in later times) whose Malay name ber-hala means possessing direction, being directive, they sailed through the gap between the Lingga and Tujuh Islands, clearing the Riau-Lingga group as fast as they could with, a southeastern monsoon wind astern. Only after they were well out to sea and out of range of the island sampans (at least their operation in swarms), they turned north into the gulf, heading for that part of its coast which they knew to be friendly. Because Ptolemy converted each course into a coastline, each change of course meant a bend in that coastline or a promontory to round. ${ }^{2}$

I. The West Coast of the Great Gulf

Ptolemy's Megas Kolpos has been assigned various locations, ranging from the Gulf of Bengal ${ }^{3}$ to the Gulf of Martaban, ${ }^{4}$ the Gulf of

1. This article is a continuation of my "Suvarnadvîpa and the Chrysê Chersonêsos," Indonesia, No. 18 (October 1974), pp. 1-40.

2. See ibid., pp. 5-10.

3. Ph. L. Eggermont, "The Murundas and the Ancient Trade Route from Taxila to Ujjain," Journal of the Economic and Social History of the Orient, IX (1966), p. 269 .

4. To the authors of the nineteenth century mentioned by $P$. Wheatley in his The Golden Khersonese (Kuala Lumpur: University of Malaya Press, 1961), p. 144, we 
Siam ${ }^{5}$ and the northern bowl of the South China Sea. ${ }^{6}$ It will be clear from the first part of our study that we are steering Ptolemy's voyagers straight into the Gulf of Siam and along the east coast of the Malay Peninsula. We have to look there for, successively, 7 Thagora; the capital city Balong(g)a (or Balang[g]a); the region Throana; the mouth of the river Doanas (or Daonas); the royal center Kortata (or Korthata); the settlement (poleis) Sinda; the region Pagrasa; the mouth of the river Dorias; and the region Aganagara, the last stop before the Silk River (VII.2.7).

We will start with the "metropolis" of Balonga, since this was probably a feature of some prominence and may therefore be traced in other sources. When we reconstruct some of the Sanskrit from which Ptolemy derived his toponyms, it appears that his Greek transcription often used a gamma where more modern transcriptions put a "k." Compare, for example, Sagala and Sâka1a, Eragassa and Erakaccha, Kognandaba and Kokanâva. Thus the second part of $\mathrm{Ba}-1$ onga could well represent Lankâ, the name of a kingdom on the eastern shore of the Malay Peninsula, well known from Chinese sources since the early seventh century, and mentioned also in Indian (1030), Arab (1511), Javanese (1365), and Malay (eighteenth century) literature. Though all these sources date from much later than the time of Ptolemy, they are of a type that often transmit materials much older than the sources themselves. Thus the Liang Shu, compiled in the early seventh century, contains reports about Lankâ that date from the sixth century or earlier, and one of these reports states that according to the inhabitants "their country was founded more than four hundred years ago." 8

The objection will be made that the name of this kingdom was not simply Lankâ but, as commonly noted in the sources, Langkâsuka, pleasant Langkâ. In any case this is true for the later non-Chinese sources. However, the old Chinese phonograms, mostly seeming to represent sounds that more or less correspond with the Langkâsuka of the non-Chinese sources, sometimes denote simply Langkâ and once Kâmalankâ, which is a synonym for Lankâsuka. Using synonymous names was, and is, common practice, both in India and in Southeast Asia. ${ }^{9}$ Therefore, though the single syllable "ba-" is not very revealing, it may stand for another

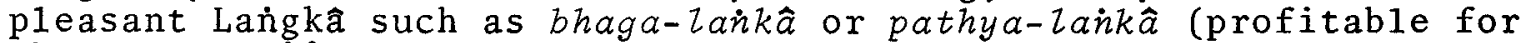
the voyage).10 I even doubt whether this kingdom already had an estab-

may add J. Pijnappe1, "Ptolemaeus en de Indische Archipel," Bijdragen tot de Taal-, Land-, en Volkenkunde (BKI), III (1870), pp. 36-68.

5. E. H. Bunbury, A History of Ancient Geography among the Greeks and Romans from the Earliest Ages till the Fall of the Roman Empire (2 vols.; New York: Dover Publications, 1959), II, pp. 606-7; R. Hennig (ed.), Terrae Incognitae (4 vols., 2nd ed.; Leiden: E. J. Brill, 1944), I, p. 407.

6. Wheatley, The Golden Khersonese, p. 146.

7. We pointed out in the previous article ("Suvarnadvîpa and the Chrysê Chersonêsos," p. 32) that when no specification (town, emporium, and so forth) is given, the feature always appears to be a region.

8. For a synopsis of the data about Langkasuka, see Wheatley, The Golden Khersonese, pp. 252-67; the passage cited above, p. 254.

9. Ibid., p. 279. Majapahit used several Sanskrit aliases.

10. Syllabic losses are not uncommon in the Ptolemaean manuscripts. A change from $\mathrm{p}$ to b occurs, though seldom: Lampâka-Lambagai, Pâtaliputra-Palibothra. 
lished Sanskrit name in the second century. There is no reason to suspect that it was founded by Hindus or under direct Hindu influence. More likely, the kingdom resulted from the expansionist policy of a local tribe and its chief, and the name came from the indigenous name of the central area of the kingdom. The location attracted foreign traders and thus Hindu influence. But it may have been a long time before the kingdom officially took a Sanskrit name in tandem with its original one. In the meantime various Sanskrit reports could devise different names, but if these names took the indigenous name as their starting point, they would be only variations on a common theme. One version might have become more common, without being "official."l

We are not informed of the exact position of Balonga, but the sources point to the vicinity of Patani. Thus a map added to the Wupei Chih (c. 1628, therefore a rather late source) locates it immediately north of that town. In the course of its long history its center may, however, have been moved several times in the event of a change of rulers or if the original site, for example, was occupied or destroyed.12 In any case, its general location is sufficiently certain and tallies too well with that of Ptolemy's Balonga to leave open the possibility that another Langkâ could be meant. The number of Southeast Asian kingdoms at the time can hardly have been so many that we could reasonably expect to find the same name twice in the same vicinity.

The other metropolis along this coast lay further north and was called Kortata by Ptolemy. The reading Kordathra preferred by Renou is certainly less felicitous. The majority of the Greek manuscripts have Kortata or Kortatha, to which may be added those that differ only because of metathesis and read Kotartha or Katartha. The Latin manuscripts incline equally to Chortata, Corthatha, Cartata, and so forth.13 The first section of this name, most frequently spelled Kor-, may safely be connected with the modern name Kra in the circumstances without discussing whether the first or the second form was created through metathesis, a phenomenon that in any case turns up everywhere and in every form in the Ptolemaean manuscripts. The second part is more interesting. The Sanskrit tata means spread out, extended, wide, and is thus the exact equivalent of Malay bambang or pampang (spread out, wide). This in turn is in accord with the name $P^{\prime}$ an-p'an applied by Chinese sources to a kingdom in the Kra region which, according to the same sources, cannot have originated much later than the founding of Fu-nan. This $P^{\prime}$ an-p'an, moreover, is said to "adjoin the kingdom of Lankâ" to the north and to have sent envoys to the Chinese court since 424 A.D. The people were Buddhists.14 Though names are unpredictable,

11. The origin of the name Lanka may have been the whim or the Indian patriotism of the Brahmanic or Buddhist adviser who first engineered the Hinduization of a local "yang dipertuan"'s residence. There might also have been an inducement, in the form of a local toponym such as the West Javanese Maja-lengka (the bitter maja, a medicinal tree) or Ci-calengka (bamboo river). Here it would have expressed something that was pleasant or profitable, like 0ld Malay Pelangkah (auspicious), or the Malay original of the Thai Patthalung on the Luang lagoon which might have been the initial site of the kingdom. Paluang means repose.

12. J. G. de Casparis, Selected Inscriptions from the 7 th to the 9th Century, A.D. (Bandung: Masa Baru, 1956), p. 299.

13. L. Renou, La Géographie de Ptolémée, L'Inde (VII.1-4) (Paris: E. Champion, 1925), p. 47.

14. Wheatley, The Golden Khersonese, pp. 47-51. 


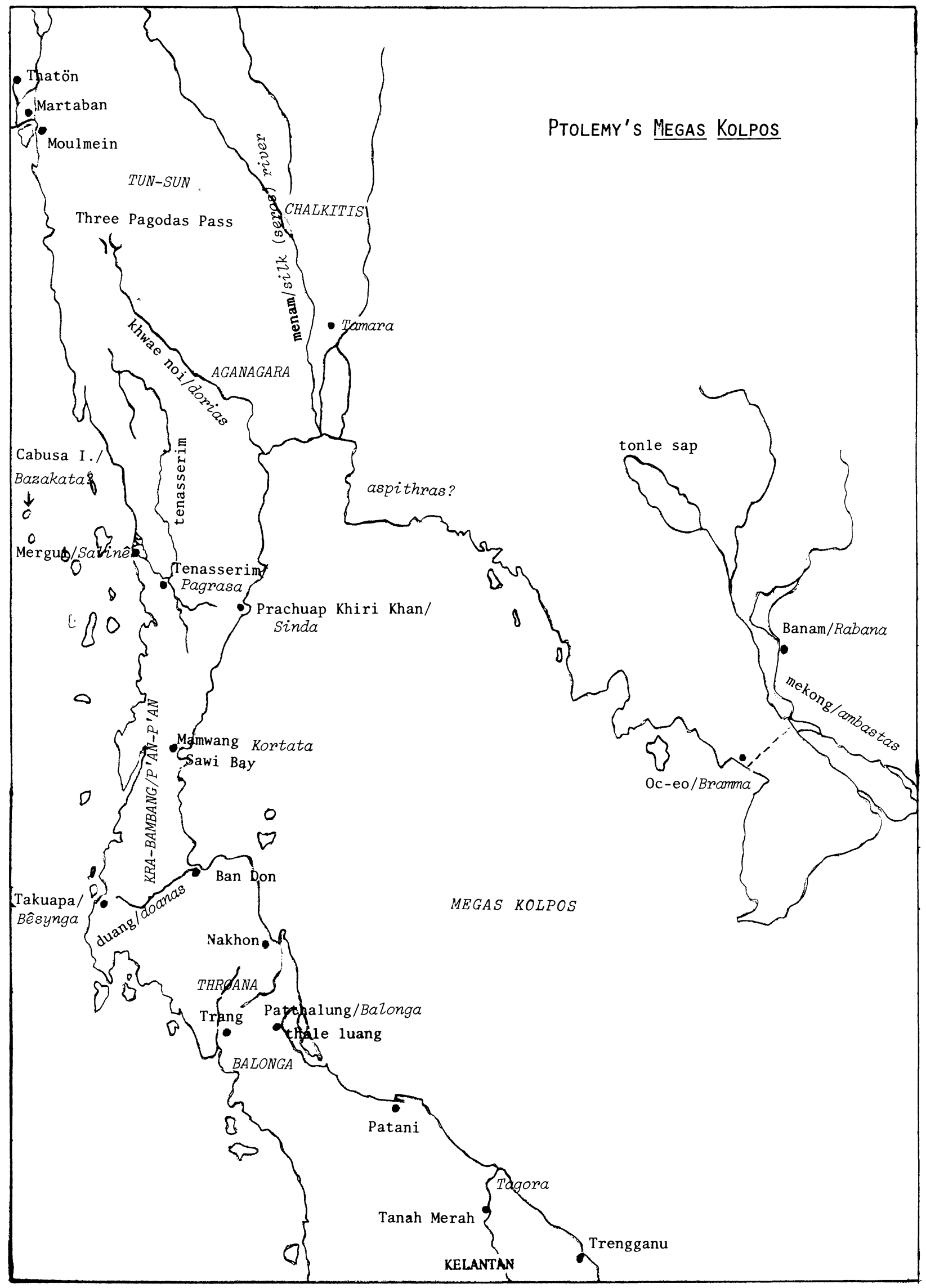


the name Kra-Bambang might have been derived from the elongated shape of the kingdom south to north in the mid-Malay Peninsula.15

The first of the lesser features in Ptolemy's 1ist is the Thagora region south of Balonga which supposedly held some attraction for foreign traders. The only place for which we have early documentary evidence attesting to its attractiveness which also has the required location, is the Buddhist kingdom of Ch'ih-t'u or Red-Earth-Land (though it was not yet a kingdom in Ptolemy's time). In the early seventh century it was singled out for the honor of receiving a Chinese embassy as part of an overall plan for developing Chinese trade relations overseas. The "tribute" brought back by the envoys consisted of local products similar to those of Tongkin, and also camphor and gold. Wheatley showed convincingly that this kingdom must have been located along the banks of the Kelantan River.16 If the soil that gave Tanah Merah its name "derived from sedimentary rocks... (which) on weathering become reddish or orange, or may be bleached white,"l7 the Ptolemaean name Tha-gora may also have been connected with it. The Sanskrit gaura means whitish, yellowish, reddish, while the solitary Tha- may derive (I do not see any other possibility) from tapta, heated, scorched. It may have stressed, however, not so much the red color as the bleached appearance of the earth in accordance with the name Kelantan. The word kelantang is common to most Indonesian 1 anguages and means "to bleach in the sun."18

The next stop after Langkâ was the region Throana. Its most likely location from the geographical point of view would be the Bay of Nakhon. This place also has an archeological past. It was the site of the old Ligor and probably the center of the Tâmbralinga or Tâmralinga region (afterwards the kingdom of the Dharmarâja). A Tâmbalinga is mentioned in the Nidessa, the second century Pali version of the Buddhist canon and both Sylvain Levi and George Coedes feel sure that this toponym indicates the later kingdom of Tâmbralinga, whose origins must therefore go back at least to the second century.19 However, it is difficult to conclude that Throana derived from the Sanskrit tâm(b)ra or tâmravana. 20

15. The metropolis Kar-Bambang may have left its name to the modern Don Mamwang, on the Sawi Bay.

16. Wheatley, The Golden Khersonese, pp. 26-36.

17. Jin-Bee Ooi, Land, People and Economy in Malaya (London: Longman's, Green \& Co., 1967), p. 67.

18. The name Kelantan is probably a Hinduized form of Kelantang.

19. G. Coedès, The Indianized States of Southeast Asia, ed. and trans. by W. F. Vella and S. B. Cowing (Honolulu: East-West Center Press, 1968), p. 39.

20. One could also consider a connection between Throana and the modern Trang. The voyagers might have traded from their anchorage in the Bay of Nakhon with the people of the Trang basin or have taken on passengers who were returning from such an expedition and wished to continue by sea. If, however, the Taragha related by Ibn Sa'id in the thirteenth century indeed indicates modern Trang (Brian E. Colless, "The Ancient History of Singapore," Journal of Southeast Asian History, $X$ [1969], p. 4), this place name is more likely derived from Sanskrit taramga (moving like waves, surging) and thus is not a very convincing candidate for being the matrix of Ptolemy's Throana (or Thoarna as one manuscript spells it). 
Ptolemy's Doanas (dhvâna, murmuring?) or Daonas (dhavâna, washing, running?) river mouth does not come as a surprise. This is the mouth of the Duang or Khirirat River flowing into the Bay of Ban Don. The river originates near Takuapa, probably Ptolemy's Bêsynga or Bahihsimha(la), and guides an overland route from there to Ban Don. In spite of the fact that archeological evidence does not seem to go that far back, 21 the route was probably already in use during the first and second centuries.

After the visit to the metropolis of Kra-Bambang the voyagers supposedly dropped anchor at an ordinary kampong Sinda and somewhere along the coast of the region of Pagrasa. This must bring them to the latitude of Mergui and Tenasserim. The more original Malay version of the name Tenasserim has been preserved in the Tanasârî (Tanah Sari) of the Arab sources.22 The Sanskrit equivalent of Maiay sari (plant essence, probably meaning aromatics) is rasa. The first section Pag- is therefore most probably the remnant of bhâga, country, the translation of Malay tanah. Thus Pagrasa indicates the country of aromatics (or the country called aromatics), currently known by the name of Tenasserim.

Since through the valleys and passes of Tenasserim runs one of the most frequented overland routes that crosses the Malay Peninsula, ${ }^{23}$ we will have to look on Sinda as an eastern terminus on this route. It may therefore have been located in the vicinity of Prachuap Khiri Khan. If we interpret Sinda as a derivation of siddha, a spirit or charm, ${ }^{4}$ and the equivalent of the Malay hiyang, we might point to modern Huai Yang as its possible descendant.

Our last two stops before we arrive at the Silk River are the mouth of the river Dorias and the region of Aganagara, both very probably located in Mon territory. The name Dorias is derived from Sanskrit dvârya--pertaining to the gate. The most likely gate in this area is the Three Pagoda Pass, the principal gateway for the caravans on the overland route from the West to the Menam and Mekhong deltas and to Annam. The Khwae Noi River, which descends from near this pass, guided the caravans to the fertile lowland, reaching the coast south of Ratburi. This is obviously the river "pertaining to the gate." In the middle of the sixth century, as a result of the disintegration of Fu-nan, a new or renewed kingdom came to the fore in these environs. Its name Dvâravatî, like that of its Indian predecessor, is usually translated City of Gates, but could here more suitably be interpreted The Portress or The Guardian of the Gate. ${ }^{25}$ The region of Aganagara (Mountain City) may have been part of the Tun-sun of the Chinese sources.

21. A. Lamb, "Miscellaneous Papers on Early Hindu and Buddhist Settlements in Northern Malaya and Southern Thailand," Federation Museums Journal, VI (1961), pp. 48-55.

22. Wheatley, The Golden Khersonese, fig. 41 (opposite p. 240). The Chinese call it Ta-na-su-1i, probably from Tanah-sĕri (ibid., p. 94).

23. M. Collis, Siamese White (London: Albatross Library, 1947), pp. 27-30, 237-38; D. F. Lach, Asia in the Making of Europe (Chicago: University of Chicago Press, 1965), I, pp. 519-38.

24. See "Suvarnadvîpa and the Chrysê Chersonêsos," p. 30.

25. About Dvâravatî, see G. Coedès, Les États Hindouisés d'Indochine et d'Indonésie (2nd ed.; Paris: E. de Boccardi, 1964), pp. 145-47. 
II. From the Silk River to the River Sinos

The Liang Shu has a passage about a certain kingdom called Tun-sun that, judging from the description, must have encompassed the northern part of the Malay Peninsula (maybe down to Tenasserim), but held sway also over the north coast of the Gulf of Siam. Wolters, who translated this passage and commented on it, showed conclusively that it is part of an early third century report.26 Since this report gives the impression that the kingdom was then a well established and widely known entity, it seems fairly certain that it already must have existed at the time Ptolemy's source visited the country. The Chinese report stresses the fact that the kingdom was in communication with both India and Parthia to the west and Tongkin to the east: "All the countries beyond the frontier come and go in pursuit of trade. . . At this mart east and west meet together, so that daily there are innumerable people there. Precious goods and rare merchandise--there is nothing which is not there." 27

It may have been that the principal center of this activity lay along the west coast of the peninsula and that this region was the first objective of the western traders, who must have constituted the majority of those "in pursuit of trade." But it cannot be doubted that these people from the first century onwards had gone further than their first objective by crossing and circumnavigating the "gold-belt" of Suvarnabhûmi-Suvarnadvîpa 28 in the hope of finding a new way of communicating with the City of the Chinese, whose goods were known to them because they had reached India for centuries along other channels of trade. 29 The author of the Periplous heard rumors about this (at the time evidently not yet very successful) movement, while navigating the west coast of India. Somewhere behind Chrysê Island, he was told, the sea penetrated far inland to the north, into a country in whose center Thinai was located. But only a few traders were able to journey that far, because the country was extremely difficult of access. 30

26. 0. W. Wolters, Early Indonesian Commerce: A Study of the Origins of Śrîvijaya (Ithaca, N.Y.: Cornel1 University Press, 1967), pp. 44-46. See also Wheatley, The Golden Khersonese, pp. 15-21.

27. Wolters, Early Indonesian Commerce, p. 44.

28. This "belt" may have been what was intended by the Chinese "kin-lin" and the Sanskrit "Suvarnakuḍa" mentioned by Coedès, Les États Hinduisés, p. 82.

29. The northern road through Baktria, that supplied also West Asia and Rome, is sufficiently known. The way to the Ganges mouth may have run through Lhasa (W. Willets, Chinese Art [Harmondsworth: Penguin Books, 1958], I, p. 218), but it is certain that already in the second century B.C. a route existed from Shu (Szechwan) and Yunnan through the valleys of the upper Irrawaddy and Salween to the Ganges mouth. The Han emperors became painfully aware of this fact when they started to look for a southern route in order to avoid the Parthian middlemen in the north and their prospectors simply vanished one after the other. There were evidently people who did not want to be spied upon because they had too much to lose (Ying-shih Yü, Trade and Expansion in Han China [Berkeley: University of California Press, 1967], pp. 112-17; W. Purcell, The Chinese in Southeast Asia [2nd ed.; London: Oxford University Press, 1965], p. 8). The latter (p. 86) mentions also a branch road that should have existed "since ancient times" from the Salween through the Shan States to the Menam valley.

30. C. Müller, Geographi Graeci Minores (Paris: A. Firmin Didot, 1855), I, p. 285 (Periplus, 64), according to the interpretation of Hennig, Terrae Incognitae, p. 386. About the Periplous see "Suvarnadvîpa and the Chrysề Chersonêsos," p. 3 . 
The situation must have improved drastically because Tun-sun became "an essential trading link between the western Indian Ocean and southern China."31 The location of Tun-sun makes it clear that this lively trade was essentially an overland affair. This is certainly the case for those traders who came down into the Menam valley by way of the Three Pagoda Pass. However, it is equally true for those who circumnavigated Chrysê Island and reached Tun-sun by way of the Gulf of Siam, or those who used the Tenasserim crossing or one further south and joined our voyagers somewhere on their way up to Ptolemy's Silk River, the modern Menam or Chao Phraya. Rather than waiting there for months until a change of monsoon made the return trip south and the crossing to Iabadiou possible, they would have used the time to journey inland as far as the rainy season permitted them to travel. ${ }^{32}$ Thus wherever the center of Tun-sun may have been, the valley of the Menam must have had its share of the trade activities as a region of transit, as a starting point, and maybe also as a meeting point between East and West. 33 No wonder that Fu-nan exerted itself to the utmost in order to make these kingdoms its tributaries and thus to establish its hegemony over the land road. In the early sources, the bellicose nature of the Funanese is more evident than their trading activity. This Malay people was probably like the people of Aceh or Makassar ${ }^{4}$--not peaceful middlemen, but, like Vikings and adventurers, on the lookout for booty and domination where possible.

The fact that Ptolemy here only mentions a river mouth and does not speak of an emporium is immaterial. The source reporting this part

31. Wolters, Early Indonesian Commerce, p. 44.

32. In order to be sure of a good wind for clearing the islands, they would not have started from Jambi before April-May on their outward voyage. A lively description of a coastal voyage along the east coast of the Malay Peninsula (or at least part of it) is provided by Abdullah bin Abdul Kadir's The Voyage of Abdullah from Singapore to Kelantan in A.D. 1838, translated by A. E. Coope (Kuala Lumpur: Oxford University Press, 1967). He started at the end of March, but encountered promptly "a storm from the east" on his first day out. Thus if our voyagers waited until April-May in order to be on the safe side, they may have arrived at the Silk River in July during the rainy season. Since they would not have been encumbered by heavy equipment, their main difficulty would not have been the roads, but at most some river crossings. For the crossing to Iabadiu, November would have been the best period.

33. In a much later time, but still before steam and oil disturbed the traditional pattern, the Menam River was certainly such a meeting point. The French Abbé Choisy, who was in Ayudhya in 1685, admits: "I stood frequently in admiration of the great strong city, seated upon an island round which flowed a river three times the size of the Seine. There rode ships from France, England, Holland, China and Japan. . . ." At the time the Chinese brought silk, tea, porcelain, quicksilver and bronze vessels, taking in exchange scented woods, pepper, hides and bird's nests. But especially the Indian merchants, who crossed from Mergui and Takuapa, made Ayudhya a great center for the exchange of goods between East and West, and found also a market for the Siamese home products. (Collis, Siamese White, pp. 31-33.)

34. Linguists seem to have detected special affinities between the Mon-Khmer, Cham and Acèhnese languages. See for example C. 0. Blagden, "Achinese and Mon-Khmer," Feestbundel Koninklijk Bataviaasch Genootschap van Kunsten en Wetenschappen (2 vols.; Batavia: Albrecht \& Co., 1929), I, pp. 35-38; H. K. J. Cowan, "Aanteekeningen betreffende de verhouding van het Atjèhsch tot de Mon-Khmer-talen," BKI, CIV (1948), pp. 429-510. 
of the voyage could well have been a Buddhist monk. In any case the source was not interested in trade, but knew only capitals, towns, river mouths and regions. I will reserve until the next section my formulation of a reason for Ptolemy's conclusion that the Silk River formed a part of the boundary between Further India and the region of the Sinai.

Before continuing their voyage, the traders may have made a journey inland. Their goal may have been the town of Tamara. The Chalkitis (Copper Country) of Ptolemy (2.20) that sported "numerous copper mines" could have been only one place in the whole of mainland Southeast Asia--the Phetchabun Range, the eastern boundary of the Menam val1ey. It is evident that this Tamara, east of the Menam, rightly bore the name Copper Town (tamra). Its site was most probably in the vicinity of Lopburi. We do not have similar clues to the names of other towns mentioned in this area, such as Agimoithia, Sittibêris or Kimara. Since Salatha is positioned near the origin of the Dvârya, it must have been close to the Three Pagoda Pass (Sangklaburi?). Randamarkota (as the great majority of manuscripts read the name), "a place renowned for its nard," in the upper reaches of the Sêros, must have been the town of "the jewel (that is) emerald-1ike" (ratna-mârakata), a poetical title given (probably by our source) to the greenish nard oil.

The continuation of our voyage brings us to the mouth of the Aspithras or Aspithara, a river that like the Silk River is supposed to have its source in the Sêmathênos mountains. Along the banks of the river Aspithras was situated a town of the same name as the river. This name is most likely derived from âsapitrya, which can be translated as both seat-sacred-to-the-ancestral-spirits or ashes-of-thedefunct-ancestors river. It is unusual that the Chinese reports should give such a prominent place to the description of the rather gruesome burial customs in Tun-sun, the last act of which was that the ash urns were sunk in the sea.35 Of course this would obtain for the people along or near the seashore, while elsewhere the river must have been used for the same ceremony. The river Aspithras might have been one of the eastern arms of the Menam delta, or perhaps even the Bang Pakong further east. 36

Our next desgination is a place named Bramma, which (though our source could not be bothered with mercantile detail) may also have been an emporium. I suggest that the Sanskrit matrix of this name is parama (chief-aim port or end port). Its position could qualify it as the harbor town of Fu-nan excavated by Malleret at Oc-eo. The southern peninsula of what is now called Cochin-China would at the time have been little more than a series of mud-flats intersected by channels, so that Chinese travelers could speak of "sailing across Fu-nan."37" Thus Bramma may have been connected with the southernmost arm of the

35. Wheatley, The Golden Khersonese, pp. $17 \mathrm{ff}$.

36. We do not have to attach too much significance to Ptolemy's river sources. Since only a few mountains were mentioned in his sources, those were made to serve for all his rivers. He simply stretched the rivers until they met the nearest mountain known to him. Thus the Copper Country was evidently not described as a mountain range, therefore he had to assign the Sêmathênos to these parts. We will discuss mountain ranges in our last section.

37. D. G. E. Hall, A History of Southeast Asia (London-New York: Macmillan, 1970), p. 25 . 
Mekhong by a channel that could accommodate at least the main types of vessels then in use. If so, Ptolemy's river Ambastos must have been either this Mekhong branch or the whole Mekhong River. The name is rather mysterious, since Sanskrit ambhastas means out of the water. However, this water from which the river originated could easily have been the Tonle Sap or Big Lake, which functions as a huge reservoir for the nether reaches of the Mekhong.

Obviously, our voyagers entered the river in order to reach Rabana, which earlier 38 we proposed as Râj Banam or Kurung Banam. This is indeed a place name and not, as is maintained by Coedes and others, the title of a king, ${ }^{39}$ though a king may have been considered the incarnation of the mysterious chthonic forces emanating from a nearby rock or hill. But why is the place not noted as a metropolis? We will propose an explanation for this in the next section. Sailing south (according to Ptolemy--thus really southeast) from there, apparently by one of the channels of the Mekhong, the voyagers passed the mouth of the river Sinos, sighted Cape Notion and entered Animal Gulf. We have already proposed 40 that this passage was the crossing of the South China Sea to the mouth of the Rajang River and the market-place Binatang on the coast of Borneo. Here we will supply some additional arguments for this contention.

\section{Ptolemy's Habitat of the Sinai}

It is evident from Ptolemy's world map that for him Sêrikê was no longer confined to the north of China, but that the Greeks had acquired a rough idea of its extension southward, its southern boundary already safely established as joining India-beyond-the-Ganges.4l This information could have traveled along the northern road or, equally, could have been obtained from contacts with India. As we noted above, the Indians had at their disposal a more southern connection with China and since the first centuries of our era a southeastern one as well. It seems likely that they also considered the Han-dominated Tongkin to be a part of Cîna.

It is not evident to what extent the Greeks were aware of the identity of the Indian Cîna with their own Sêrikê. Though the Greek traders of the second and third centuries, at least those who explored for themselves the far eastern trade movement, did not doubt this identity, it is not clear what the older generation, to which the author of the Periplous belonged, thought about this question. For that author,

38. "Suvarṇadvîpa and the Chrysê Chersonêsos," p. 9.

39. Coedès, Les États Hinduisés, pp. 74-75; Hall, History of Southeast Asia, p. 24. The title kurung is in diverse forms common in the eastern part of Southeast Asia, and is used both for sacred places (especially natural and architectural hills or their divinities) and persons. Thus the Krung Ayudyas, Krung Theps, and so forth, have their equivalent in the sacred mountains or rocks called karaëng loë, great lord, by Bugis and Makassarese (Encyclopedie van NederlandschIndiee [2nd ed., 8 vols.; The Hague: Nijhoff, 1917-38], I, p. 325). The Kurung $\overline{\text { Banam }}$ is primarily a King Hill and not a Hill King. See also G. Porée and E. Maspero, Moeurs et Coutumes des Khmèrs (Paris: Payot, 1938), pp. 87ff., 97ff.

40. "Suvarnadvîpa and the Chrysê Chersonêsos," p. 9.

41. India-beyond-the-Ganges "borders . . . in the north upon the parts of Scythia and Sêrikê that we spoke about earlier" (2.1). 
Thinai was the name of a city in the center of an unnamed country and also the center of the silk export to India both by way of Bactria and by way of the Ganges mouth. He never stated expressly its identity with Sêrikê. Therefore it would not be surprising if Ptolemy also did not yet know exactly where to place these Thinai or Sinai.42 His translators, certainly if they were Indians, may have had a fair suspicion that Cîna was the same as Sêrikê, but apparently they restricted themselves to transliterating it as Thinai or Sinai.

There seems no other reasonable explanation for Ptolemy's Sinai than that the name is identical with the Thinai of the Periplous and the Cina of the Indians. However, the country that is allotted to them by Ptolemy lies to the south of Sêrikê and to the east of the 1 ine formed by the Menam River, the Gulf of Siam, the Animal Gulf and the Sinai Gulf. To the south it stretches to the unknown Terra Australis, while to the east it ends in equally unknown territory. Thus for Ptolemy and his learned predecessors this Sinai was evidently an additional name that could not be identified with anything they already knew and therefore posed an annoying problem. Ptolemy's solution was to imagine that those millions of Sinai dwelled in a area the equivalent of the eastern part of Southeast Asia, with the eastern and southern boundaries stretched as far as the unknown. Was it simply despair that prompted Ptolemy to take this way out? He must have had reasons, but because his sources are lost to us, we do not know exactly what information he possessed. However, we can try to reconstruct part of Ptolemy's solution from his results.

Ptolemy's sources must have mentioned the Sinai (the Greek for the plural Sanskrit form Cina), but certainly not in connection with the entire region Ptolemy assigns to that people. They may have done so, however, in connection with the exact spot that also gave the Periplous occasion to speak of the city of the Thinai, namely the mouth of the Menam River.

The most reasonable explanation seems to be that his text added to the name Silk River the explanation that it was so named because, after crossing it, one (eventually) arrived in the country of the Sinai. In that case Ptolemy must have taken the name Silk River for granted, and understood the explanation concerning the river's relation to the Sinai as only an additional piece of information since he was unaware of the connection between silk and the Sinai. Moreover he must have understood this addition to mean that by crossing the river one (immediate1y) set foot ashore in the country of the Sinai. Thus instead of simply giving this addition, which for him made no sense, he substituted for it his own conclusion: this river formed the boundary with the habitat of the Sinai.

Whatever way Ptolemy may have reached his conclusion, it must have been the first fundamental step for the solution of his Sinai problem.

42. Therefore, because of their dependence on Ptolemy, the Portuguese in India had to repeat the discovery that was already made by the Greek traders of Ptolemy's time, namely that the Greek Sêroi and the Indian Chijn (especially those of the Ming voyages) were the same people (C. R. Boxer, The Christian Century in Japan [Berkeley: University of California Press, 1951], pp. 4-5). Ptolemy's information about Thinai city was certainly less than that of the author of the Periplous. If not, he could never have placed it on the eastern boundary of the inhabited world, where it could hardly have functioned as an important center of silk trade. Its connection with silk was completely unknown to him. 
The extension of their region southward must have been effected by Ptolemy's awareness of the river Sinos. He knew that his sources frequently called a people by the name of the river along whose banks they were supposed to live. Thus he accounted for the Gangeridai, Bêsyngitai, Daonai, Aspithrai and Ambastai. Since here also he was confronted with two names, for a people and a river, which were similar, it was natural for him to assume that the people and the river belonged together. Now the river Sinos came evidently from the south. His sources mentioned another river emptying into it at the equator, which was six degrees south of where Ptolemy located the mouth of the Sinos. Still another river, the Kotiaris, which Ptolemy thought must be a branch of the Sinos tributary, ended in a certain Sinai Gulf seven degrees south of the equator, while the town of Kat $(t) i g a r a$, over a degree south of that, was said to be an anchorage of the Sinai. If here, on what he considered to be the southern limit of his "known" world, there were still Sinai to be found, the river Sinos had to originate from beyond this limit. Ptolemy even refrained from giving the river a source--highly exceptional to his usual practice.

But how do we explain that the Ptolemaean text re-made the South China Sea into a river? If this was really what happened, there would be no feasible explanation. It seems much more probable that the South China Sea did not exist as a conception at that time. Some centuries afterwards, the Chinese Chang-hai may have represented an entity that was similar to our South China Sea, 43 but it is at least very doubtful that indigenous or Indian traders knew a comprehensive name for this sea when Ptolemy's informants visited the area. What may have existed was some kind of trade route, called Cinavaripatha (China waterway) or something similar by these informants. It would most likely branch off from the crossing to Fu-nan somewhere between Cape Notion and the Funan coast and contact the Annam coast at a safe distance from Fu-nan. 44 It is likely that Ptolemy's Greek translator (no explorer himself) decided that potamos (river) would be the best translation for this unknown feature, and Ptolemy, in order to save his uninterrupted coast line, had to provide this river with a mouth there and then, and to assign it an inland course generally parallel with his coast line.

43. Wheatley interprets "Chang-hai" as Gulf of Siam, while Wolters takes it to mean the South China Sea. The Tun-sun report we mentioned above includes a remark to the effect that "the Chang-hai is of great extent and ocean-going junks have not yet crossed it direct." This remark bears all the characteristics of an annotation made by the seventh century editor. It fits only as an interruption between brackets in the text, and it would suppose some kind of prophetical vision coming from a contemporary (who at most would have said-- maybe we will once be able to...). The crossing that we are going to speak about was not yet "direct" in the later sense.

44. But Ptolemy was right in his conclusion that this "water-way" must have had its origin farther south, as we will see in our next section. Therefore we will have to modify our earlier theory ("Suvarnadvîpa and the Chrysê Chersonêsos," pp. 8-9) to accept a certain amount of trading activity already coming from or by way of the Borneo coast, that by-passed Fu-nan and went directly to Tongkin and South China. Such a route was safely established in the early fifth century, in the time of Fa-hsien. But three centuries earlier (133 A.D.) Chinese reports made mention of an embassy that came from Yeh-tiao (probably Yavadvîpa), long before any of the other early kingdoms of Southeast Asia made their appearance in those annals. I doubt if many foreign traders took this road in the early stages. In any case none of Ptolemy's informants seems to have done so. 
This Chinese waterway was therefore not called Chinese because the Sinai lived on its banks, but because it formed a direct connection with the 1 and of the Chinese. The fact that Sanskrit Cina is a plural form meaning the Chinese, but used adjectively, may have added to the confusion. Though the translator seems to have coined the form Sinos for the river, in the case of the gulf and the anchorage he evidently used the literal translation "of the Sinai" (tôn Sinôn) implying that they were inhabited or visited by that people. In fact, the gulf and the anchorage were no more inhabited by Chinese than an India House or India Wharf are by Indians. They were simply stations on the Chinese trade route. It is evident that this Sinaization of Southeast Asia necessarily created a problem. Before Ptolemy had effected this transfer, his sources had already peopled the northern part of the Sinai region with Akadrai, Aspithrai and Ambastai, while in the south both the Thêriôdês and Sinai Gulfs were occupied by "fish-eating Ethiopians" $(3.1 ; 3.3)$. Whether Ptolemy thought that he could consider these peoples as part of his sinai is not clear, though once he seemed determined to force the issue by declaring all fish-eating Ethiopians to be "fisheating Sinai" (3.4).

In the whole region of the Sinai only one capital city is mentioned, and that is the inland city of Thinai. Ptolemy places it three degrees north of the equator, thus between the latitudes of Cape Notion and the Animal Gulf, but four degrees further east, in fact on the exact eastern limit of his known world.45 It seems clear that his sources had even less information about this place than the author of Periplous. For Ptolemy, Thinai lay somewhere in the center of the Sinai region, nearly inaccessible, with no record of distances or even clear direction. If Ptolemy's sources said anything about silk export from Thinai, no trace of this information was left in Ptolemy's text. He communicated only one insignificant detail: "They say that the city has no ramparts of copper, or anything else that is worth mentioning" (3.6). It could not have been more colorless. It seems therefore, that Ptolemy used the toponym Thinai in spite of his uncertainty of its location in order to allow the Sinai a capital city that was theirs by right of name. He placed Thinai as far away as he could, but at a latitude that was in the middle of the region, and warned that people had better not go there, for there was nothing, at least nothing of interest, to be found. Maybe his sources told him also that this Thinai was the sole capital of the country, a piece of information that might have induced him to regard as a mistake the designation of Rabana as a metropolis.

We have tried in this section, not only to demonstrate that Ptolemy placed the habitat of the Chinese in the eastern part of Southeast Asia, but also to explain why he came to this extraordinary conclusion. Likewise we have tried not only to make acceptable the fact that he must have crossed the South China Sea in view of the direction he took, the places he mentions, and his eventual goal, but also that he conceived of this sea as a river. Though we are no longer able to check either Ptolemy's thought processes or the actual content of his sources, we think that in the main our analysis is correct.

45. Ptolemy devised a longitudinal arrangement for the territory east of the Ganges that consisted of three zones of ten degrees: 150-160 from the Ganges to Chrysê Chersonêsos, 160-170 from there to the Silk River, and, from the Silk River to the limit of the known world, degrees 170-180. 

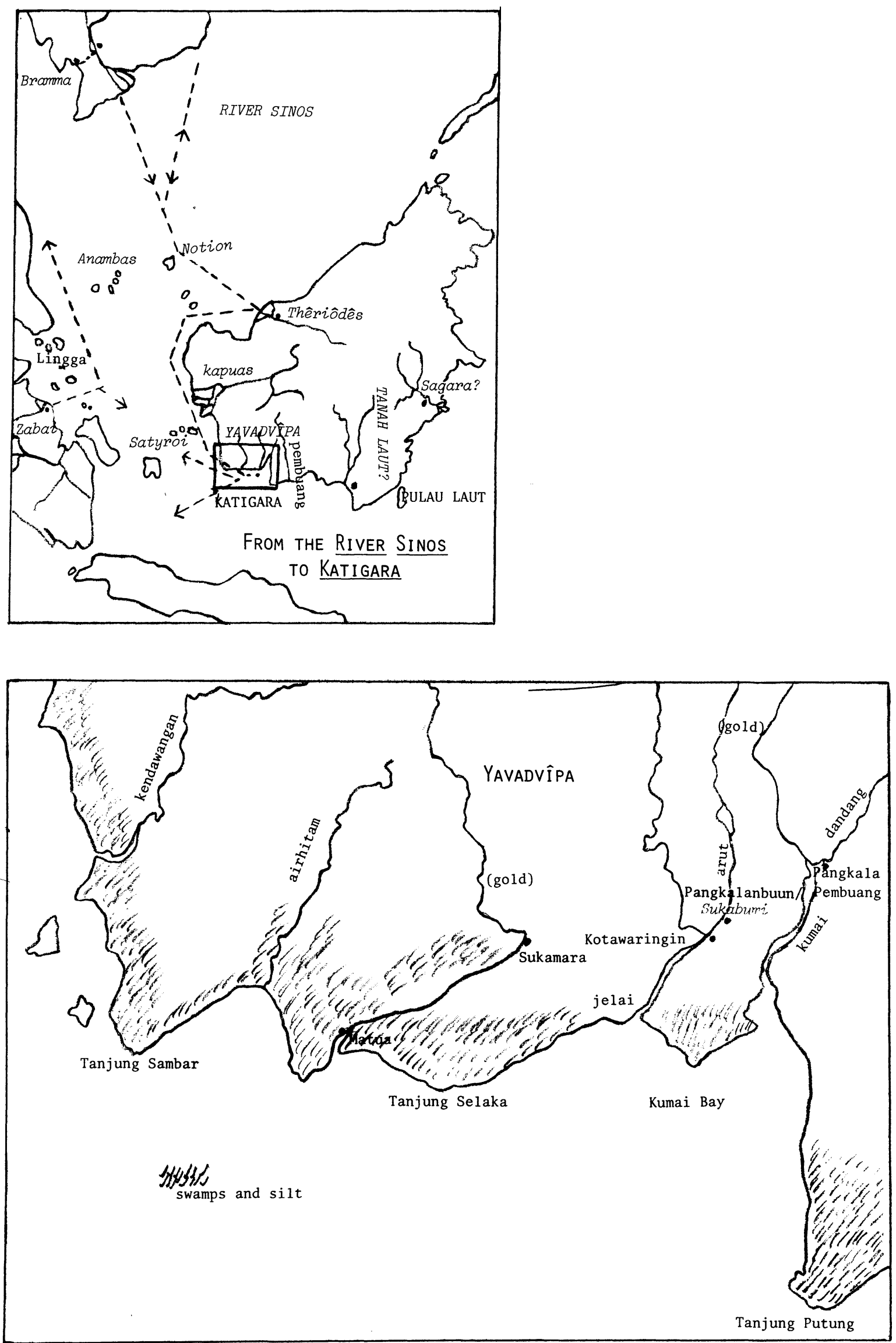
IV. From the River Sinos to Katigara (VII.3.2-6)

The first feature we should encounter after the mouth of the river Sinos is Notion Akron, presumably a Greek name meaning a moist or rainy cape. For Ptolemy, promontories or capes are general names for any kind of landmark or seamark, while river mouths primarily indicate opportunities for trade. We have associated this cape with the largest island of the Great (North) Natuna or Bunguran Besar group (the different names are used by different authors). This island, with its Ranai Peak (more than 3,000 feet) is without a doubt the main seamark on the crossing from Fu-nan to Datuk Bay.46 The name Bunguran (a kind of tree) is Malay, while Natuna sounds like Sanskrit and may indeed be a (corrupted) Sanskrit derivation in view of the fact that the Anambas group more to the west also sports a Sanskrit sounding name (anambhas means waterless, dry). If these non-Malay names are indeed of Sanskrit origin, Natuna could have developed from nati-unna, not very or not too wet, through any of the more than ten centuries of Indian shipping and cultural influence. Nevertheless it would seem that Ptolemy's Sanskrit source was already familiar with the name nati-unna, probably as an equivalent of ranai (drizzling or dripping), and that the Greek translator did his best to capture both the sound and the meaning of the original in his "notion."

This translator must have been something of a philologist who practiced comparative linguistics and observed similarities between Sanskrit and Greek words; our next toponym, the Thêriôdês Gulf (animallike, abounding in game) most probably had (as we noted earlier 47 ) its root in the Sanskrit matrix tiryagja of which modern Cape Jeriyè may still bear the imprint. Thus this translator may have specialized in translating only those names that in his opinion originated from etymologically the same word in Greek and Sanskrit. In any case the market place Binatang (a very unusual Malay place name), not far from the estuary of the Rajang must have been at the root of Ptolemy's toponym. ${ }^{8}$

Having completed their business at Binatang, the voyagers continued south. Having sighted the Satyr Promontory, they landed to visit the fish-eating Ethiopians of the Sinai Gulf. Into this gulf emptied the river Kot(t)iari(o)s (or Kut[t]iari[o]s), flowing from its junction with the river Sinos seven degrees north. Finally, the voyagers finished their voyage at the anchorage of Katigara.

The Satyr Promontory can be nothing other than the rocky main island of the Karimata group, 49 since there is hardly anything else along this muddy coast that could have been called a promontory. I am imply-

46. Crawfurd noted that this island was "visible from a ship at 15 leagues distant." (John Crawfurd, A Descriptive Dictionary of the Indian Islands and Adjacent Countries, ed. by M. C. Ricklefs [London: Oxford University Press, 1971], p. 291.)

47. "Suvarṇadvîpa and the Chrysê Chersonêsos," p. 9.

48. The most likely location of I-tsing's seventh century Vijayapura (Wolters, Early Indonesian Commerce, pp. 173-75, 322-23) may have been Datuk Bay, though if it was that far north it remains curious that East Java was chosen as one of the points of orientation, while other countries known to seventh century authors would have been more eligible for that function. Ch'ang Chün's "Po (or P'o)-1o$1 a^{\prime \prime}$ sounds more like Berhala than like Anambas or Natuna (ibid., p. 174).

49. See "Suvarnadvîpa and the Chrysê Chersonêsos," p. 20. 
ing that the voyagers did not visit any harbor between Datuk Bay and these islands. They may even have set their course at a respectable distance from the shore, halfway between the coast and successively the Serasan (Pirate) and Tambelan Islands, because this part of the coast was evidently not very safe. This accords with the fact that during this voyage, even though they must have passed the mouth of the river Sinos, located exact1y on the equator, no mouth is mentioned in the series of coastal features. The information about the junction of the Kotiaris with the Sinos is on the contrary furnished separately. This means first that they passed the mouth by a considerable distance, and second that the information about its location on the equator is fairly reliable, because it is not the result of Ptolemy's calculation and addition of distances, but must have come directly from his sources. Therefore, we may conclude that the river emptying at the equator was none other than the present-day Kapuas River, whose 8,000 square kilometers of delta (at that time maybe more) must certainly have been known to voyagers.

The Karimata Promontory is of course duly incorporated in Ptolemy's coast line and also accidentally placed on the equator. From this promontory to the mouth of the Kotiaris, Ptolemy calculates a distance of seven degrees in a southerly direction and two degrees in an easter$1 y$ direction, which taken at its face value would land us at least across the Java Sea. This would not be a great problem of interpretation, because Ptolemy made "secret crossings" elsewhere.50 Also, Sunda Strait (Sabârna) or the future Târumânagara would be an excellent starting point for the sweeping finale which finishes this part of ptolemy's itinerary, crossing the entire Indian Ocean straight to the coast of Africa. In this case the Java Sea would have been his Sinai Gulf. However, I do not think that the stated distance provides a reliable base. His calculations had simply left Ptolemy with so many degrees to dispose of, and he was determined that Katigara should be located on the extreme boundary or even in the extreme southeastern corner of his world picture.

Ptolemy's only purpose in extending the distance of this lap of the voyage may indeed have been to give his "known world" a clean finish. Apparently he chose for this purpose the eighth parallel of latitude south of the equator, and the voyage along it to the African coast represented the coastline of the unknown and uninhabited southern continent, Terra Australis. Katigara, its starting point, had to be 1ocated on this parallel, and the islands that according to modern geography would have been in the way were neatly placed on a row exactly north of this course. It seems, therefore, that if we can ever disregard a distance ptolemy offers us because it was determined by a priori considerations, it is here. Moreover, the direction, a more reliable element since it originated immediately from Ptolemy's sources, does not put us in a place whose topography agrees with the Java Isiand features we mentioned above.

We have seen earlier that if Ptolemy directed us south, we would have to make a constant correction to the southeast, to accord with present-day geography, and if he pointed us southeast, we would have to correct to east-southeast. ${ }^{51}$ Thus, starting from the Karimata

50. For example, see the crossing from the west coast of the Malay Peninsula to Northwest Sumatra, ibid., pp. 10-11.

51. Ibid., p. 27. In these latitudes the pole star is not visible, so that the voyagers probably sailed only by the sun, which gave them their approximate 
Strait, the corrected course proceeds across the southwest corner of Borneo. 52 The distance is unspecified, but clearly the first major natural point of reference encountered is the mouth of the Sungai Jelai or Barley River, which in a Sanskrit text would become the river Yava.

As early as 1869 Kern noted that the name Yava occurred in combination with both - dv $\hat{\imath} p a$ (island) and -koti (point, spit). ${ }^{53}$ Yavakoți may have been a fixed geographical point for Indian astronomers since as early as the first centuries of our era.54 But, perhaps owing to the scarcity of astronomical manuscripts preserved, we learn of its existence for the first time through the fifth century Aryabhat $\hat{r}_{y} a$ where its meridian is said to be 90 degrees east of Ceylon and 180 degrees east of Rome. The element koți appears in Ptolemy's geography, at least in the name of the Kotiaris River, but probably also in that of the Katigara anchorage. The element Yava is not represented in these names. But since the only koti that is known to us from other sources is this Yava-koți, it is most probable that the complete names of Ptolemy's two features were respectively Yava-kotivâri and Yavakoţinagara, Barley-point water and Barley-point Town. 55 Apparently the Yava specification was omitted when the information was passed on to Ptolemy, perhaps because the "-point" was a clear enough designation in maritime circles. If this surmise is true, it stands to reason that Barley Island also was connected with this river, point and town, receiving its name from these three features, as it later received its name Borneo from another shipping center in the north. 56

east-west location. The rest they called north and south, with the addition "a bit to the east" (or to the west, where appropriate). We see this in the observations of Alexander when he determines the direction from Zabai to Katigara as "south but a bit to the east," while in reality it is more east than south. The Chrysê Chersonêsos runs northwest-southeast, but probably Ptolemy would have made it run north-south even if it had in fact run northeast-southwest. This is not the whole answer to the question of the correction of Ptolemy's directions, but certainly the factors mentioned are relevant.

52. The rocky Sambar Point, which now forms the southwest tip of Kalimantan was probably still an island at the time.

53. H. Kern, "Java en het Goudeiland volgens de oudste Berichten," Verspreide Geschriften (15 vols.; The Hague: Nijhoff, 1913-36), V, pp. 305-14. He discusses here also the identity of Yavadvîpa with Ptolemy's Iabadiu.

54. Astronomers had to have fixed points in the sky and an established division of the "sky-circle" in order to describe the position of stars. Since all first geographers were foremost astronomers (who needed fixed points on earth for their astronomic calculations), they tried to devise an overall system of coordinates for earth parallel with and facilitating their astronomic studies.

55. For Koținagara see J. L. Moens, "Koținagara het antieke handescentrum op Yava's Eindpunt," Tijdschrift voor Indische Taal-, Land- en Volkenkunde (TBG), LXXXV (1952-57), pp. 437-48, who tries to locate it, however, at Oc-eo.

56. The Jelai River must have been the place where, in an older phase of (indigenous and) foreign shipping mentioned by the trader Alexander, ships made their landfal1. At that time, the mariners did not venture into the Great Gulf, but sailed from the Jambi region (Ko-ying?) "east of south" directly to Katigara, where they probably witnessed the exchange of products from China for those from South Sumatra. Shedding its barley epithet, the region might have become the Cape Country or Tanjung Nagara of the Nâgarakrtâgama, a name probably of Malay origin, but explained by Prapanca as a Javanese name. In 0ld Javanese, tanjung is primarily the name of a fragrant beach flower, the Mimusops elengi. 
In this way we might call an end to the dubious quest for a country where barley was prominent, a quest whose fruitlessness compelled scholars to look for a substitute vegetation that could be meant, and to engage in lengthy arguments about the Vedic use of Yava as a general term for grain or even for rice. 57 Ptolemy's sources were verbal artists who played with words, focusing on the interpretation of names more than the expression of agricultural facts. But even for simple mariners it was natural to fix on a clear local name rather than a commodity uncommon to the locality, or to call some really outstanding commodity such as rice by a name that was unusual and unclear, while avoiding for some reason the existing common name. The Jelai River, though rather unimportant in itself, had one unique quality--it marked the southwest point of Borneo. Therefore it could have given its name to the region around the big bay shaped like a fish trap between Kuala Jelai (Matua) and the long spit of Tanjung Puting (Point Cape), and to the rivers emptying into this bay. We will discuss below why this point and bay may have been important.

In Ptolemy's time, the name Yavadvîpa may have been applied specifically to the southwest corner of Borneo. If it ever had a wider connotation, it was certainly not the whole of Kalimantan, whose unity could scarcely have been known to those pioneer traders. This limitation of the size of Yavadvipa is clear from the dimensions of Iabadiu given in Ptolemy's island catalogue (2.29). It measures only two degrees from east to west and not more than twenty minutes north-south. Though no detailed knowledge can be derived from this information, it shows nevertheless that Ptolemy concluded from his sources that Yavadvîpa was only a small "island" (a term that he readily applied to any isolated coastal unit). It had a capital city which Ptolemy called Argyrê, Silver Town. If our interpretation of the Yavadvîpa toponym thus far is correct, Argyrê must also have been located at this southwest corner of Borneo, probably in the vicinity of modern Kumai or Kotawaringin; it may even have been another name for Katigara.

The name Argyrê could be a genuine translation of a Sanskrit.t word for silver. Modern topography seems to support this notion by providing a Tanjung Selaka (Silver Cape) just east of the Jelai estuary.58 However, it is rather curious that such a gold region would have a silver capital. Krom doubted (though for other reasons) the genuineness of the name: "One can think of two kinds of misunderstanding: an Indian word that was wrongly translated by 'silver,' or a name whose sound resembled 'argyrê'"59 and was converted into that Greek word by an early copyist. The latter might have been operative here if for example

57. For a short summary see N. J. Krom, Hindoe-Javaansche Geschiedenis (2nd ed.; The Hague: Nijhoff, 1931), pp. 58-59. For a lengthy discussion see G. Rouffaer's entry in Encyclopedie van Nederlandsch-Indië (4 vols.; The Hague: Nijhoff, 18991905), IV, p. 364. The name Sungei Jelai is found also on the Malay Peninsula as a name for part of the upper course of the Pahang River and a tributary of the Muar River. But these are not coastal features (E. H. G. Dobby, Malaya and the Malayans [London: University of London Press, 1955], p. 75). As for the antiquity of the Jelai toponym, I can only argue that the names of rivers do not change very often, and that it is difficult to see from where else the Hindu traders obtained their Yava toponym.

58. H. J. Schophuys and L. W. Hannibal, Peta Kalimantan disusun oleh bagian planologi Djawatan Kehutanan (Bogor: Pangkalan Persatuan Serikat Polder Kalimantan, n.d.), sheet 16 .

59. Krom, Hindoe-Javaansche Geschiedenis, p. 60 . 
Argyrê was a misreading of the Sanskrit agragira, mountain extremity or promontory. The name Tanjungnagara (Capetown) would in any case have been more congenial with Koținagara than Silver Town.

However, there is still another difficulty, namely additional information in Ptolemy which locates Argyrê "at [the] western extremity" of the island. If we assumed that the source who provided Ptolemy's island catalogue included the west coast of Kalimantan in the notion "Yavadvîpa" we might understand "at its western extremity" to mean "at the extremity of the west coast of Yavadvîpa," that is, the southwest point, because the voyage went from north to south. However, this same source provided Ptolemy with the base for calculating a distance of twenty minutes from the north to the south of Iabadiu. Therefore, it is unlikely that the whole or even a considerable part of the west coast of Kalimantan was included in this toponym. It seems more likely that the source's notion of Yavadvipa included a larger part of the south coast.60

Some additional evidence may be derived from one of Ptolemy's inland features. To the northeast of the Kotiaris mouth Ptolemy locates a town or settlement whose name is spelled Kok(k)oronagara by most manuscripts, while others have Kok(k)osanagara (or the shorter Kokonagara). The only derivation which seems possible is one starting from Sanskrit kâka, crow. It is likely that in long words such as the name of this town each copyist did his own overlooking of a syllable, so that the existence of Kokosanagara might indicate that the original had been Kâkasarânagara or Crowbrook Town. One of the regions of Tanjungnagara (Borneo) enumerated in the Nagarakrtâgama as existing in the time of Majapahit is a certain Kadandangan, which can be translated as Crow Country. Why this country is commonly connected with the river Kendawangan, which empties at the west coast,6l is far from evident, since there is a river Dandang (Malay and Javanese for crow) which empties from the northeast into the Kumai estuary. A location for Kokosanagara along the Crow River seems more probable. This would also provide room for I-tsing's Tan-tan.62

60. There is a good possibility that the text has been corrupted. As a rule, coordinates for the supposed western and eastern extremities of an island are given successively in Ptolemy. However, those for Iabadiu do not follow this pattern. The text giving Iabadiu's coordinates is usually read as follows: "Iabadiu has a capital called Argyrê situated at its western extremity, at $167-830^{\prime}$ south; the eastern extremity of the island is at $169-810^{\prime}$ south." If a punctuation mark is moved from after "western extremity" to after Argyrê, the more usual presentation of coordinates results: "Iabadiu has a capital called Argyrê; its (the island's) western extremity is situated at $167-830$ ' south. . . ."

Thus, I withdraw my earlier proposal ("Suvarnadvîpa and the Chrysê Chersonêsos," p. 9) that Argyrê should be connected with the Selakau toponyms on the west coast. The voyagers did not visit these places, and thus did not consider them a part of Yavadvîpa.

61. Th. G. Th. Pigeaud, Java in the 14th Century (5 vols.; The Hague: Nijhoff, 1960-63), IV, pp. 31-32; V, map 4 .

62. For the river Dandang see Schophuys and Hannibal, Peta Kalimantan. Tan-tan is discussed by Wolters, Early Indonesian Commerce, pp. 199-205, 332-33. I would place Tan-tan next to $\mathrm{P}^{\prime}$ en-p'en or Pu-p'en (Pembuang) between Ho-ling and $\mathrm{P}^{\prime} \mathrm{o}-$ 1i. I-tsing's discussion of this area points to an already rather strong Javanese influence along the south coast of Borneo during the seventh century. According to the Encyclopedie van Nederlandsch-Indië, VII, p. 1083, the "Kudangan" (Kedandangan?) dialect shows a strong affinity with that of Minangkabau, while in general the Malays of the southwest coast of Borneo seem to 
It will not be easy to explain why this corner of Borneo earned its fame. The conditions here are in general not much different from those elsewhere, not better but also not worse. The beaches are for the most part sandy and the broad mouths of the Kumai and the Waringin provide a sufficient anchorage. There are still places in the interior that produce a certain amount of gold. These may once have been more abundant and more accessible, but it is doubtful whether they ever could compare with those of the west coast or the region of Banjarmasin. ${ }^{63}$ The reputed fertility of this region too, whether meant to indicate abundance of forest products, rice, fruits or other foodstuffs, can hardly have been outstanding in view of the limited potential of the soil and the meager resources of the present day.64 We must take into account of course the likelihood that the country deteriorated and became impoverished through misuse of the soil, oppression and emigration, where once it may have flourished under a 1 arger and more vigorous population. But even if the Indians were impressed by the lush vegetation, the rich variety of fruits and birds (and the birds' magnificent plumage), things they rarely found in their own country, this could scarcely account for the exceptional position they allotted to Barley Point.

This position must have been determined mainly by its standing as a meeting point of shipping lanes and therefore "an anchorage of the Sinai," not the Sinai of Ptolemy's diaspora, but the real ones--the indigenous shippers of the South China Sea, Malay, Dayak and others.65 Therefore it must have already been an established center before the Hindu traders appeared on the scene and must have lost nothing of its importance after their appearance. First it was located at the end of the Java Sea, the central emporium for the products from East Borneo

claim descent from immigrants from that country, who in that case must have arrived by way of Sunda Strait.

63. Nevertheless even in the beginning of this century the Dayak people, in addition to many other exactions, paid a tax in gold to the Malay sultan of Kotawaringin. Before that time they paid such a tax to the sultan of Banjar. Its amount must have been sufficient to make a chair of gold (J. J. Ras, Hikajat Bandjar [The Hague: Nijhoff, 1968], pp. 618-19; J. Noble, Notes sur Borneo [Coulomiers: Paul Brodard, 1921], pp. 78-79). The attraction of a harbor may be time-tied and dependent among other things on the exhaustion of resources and the finding of richer deposits elsewhere. Thus Van Warwyck, one of the Dutch pioneer traders, said of Sukadana on Borneo's west coast: "This place has little to offer except some diamonds which the natives washed out of the river gravel in the interior. These few diamonds lent (in the past) more glamour to the town than it deserved and led to several useless trading ventures." (G. Masselman, The Cradle of Colonialism [New Haven: Yale University Press, 1963], p. 159.)

64. In 1939 the region was barely self-supporting in rice, but had an abundance of fish in a number of lakes (as for example lake Gelinggang near the mouth of the river Jelai): Encyclopedie van Nederlandsch-Indië, VII (1935), pp. 1082-84; VIII (1939), p. 1890. About the soil in general, E. G. J. Mohr, De bodem der tropen (2 vols.; Amsterdam: De Bussy, 1935), II/2, pp. 292-323.

65. Wolters, Early Indonesian Commerce, pp. 150-55. Note especially the connection of the Ma'anyan Dayak with the voyages to Madagascar. This people now lives pushed back into the interior by Banjarese expansion. (A. B. and J. M. Hudson, "Telang: A Ma'anyan Village of Central Kalimantan," in Koentjaraningrat [ed.], Villages in Indonesia [Ithaca, N.Y.: Cornell University Press, 1967], pp. 90-93). The mysterious Ch'ien Han Shu report speaks already of "the trading ships of the barbarians" (Ying-shih Yü, Trade and Expansion, p. 172). 
and East Java, from the Lesser Sunda Islands and the Moluccas. For the foreign traders it meant a link with the unknown world beyond, the world still closed to them. On the other hand it had direct communication with the Sunda Strait and Southeast Sumatra and was the starting point of the water-way along which the products of these regions found their way to China. For the foreigners, both those who sailed the Great Gulf and those who returned home after completing their voyage to Zabai, 66 Katigara was the last station in these parts and thus the starting point for their home voyage through the Sunda Strait. When they began to take part in the China voyage, maybe a century before the time of Fa-hsien, Yavadvîpa became also their first pied-à-terre after passing through the Sunda Strait. And from Yavadvîpa, they began their voyage north.

The fact that this center was already a meeting point before the arrival of foreign traders and possessed a certain tradition of trade and exchange, some facilities and a measure of security maintained by a local or immigrant chief with the necessary initiative and backing, made it into a haven in a land where nearly all the coasts were still inhabited by "cannibals," people lacking the stage of development that appreciates the long-range profit from trade more than the immediate but accidental yield from plunder. Even the traders themselves were not immune, becoming pirates where they could do so with impunity, engendering hostility among the indigenous peoples against themselves and those coming after them.

Looking down on this scene from the height of nearly twenty centuries, it may be impossible for us to understand all the factors that were important in this slow tidal movement of trade, and important for the people toiling frantically with small amounts of goods valued out of all proportion relative to modern economic standards, and thus to understand the reasons that determined their choice of an "anchorage." Both the toponymical and geographical correlates we propounded above, however, point to the southwest corner of Borneo as the site of Barley Point--the once famous Yavadvipa. The pilgrim Fa-hsien summarizes his impression of a "five months or so" sojourn in Yeh-p'o-ti (Yavadvipa) with the disgruntled statement: "heresies and Brahmanism were florishing, but the faith of Buddha was in a very unsatisfactory condition. "67 It is a pity that these Brahmans did not leave us a few inscriptions as they did in Kutai and Târumâ at that very time, or if they did, that the inscriptions are now lost. 68

66. This was the itinerary of the trader Alexander. See "Suvarnadvîpa and the Chrysê Chersonêsos," p. 8 .

67. Wheatley, The Golden Khersonese, p. 38 .

68. H. Kern in an address of 1882 to the Netherlands Royal Academy (Verhandelingen en Mededeelingen van de Koninklijke Akademie van Wetenschappen, afdeeling Letterkunde, Litt.2/IX, pp. 185-186) and in "De invloed van de Indische beschaving op Java (1906)," Verspreide Geschriften, XV, p. 184, contemplated placing Yavakoți in Kutai. But this Tunjung Kute (Lotus Point) of the Nâgarakrtâgama is not mentioned in inscriptions of the fifth century. Moreover I do not see how Ptolemy's course could lead us there, and it has no connection with the name Yava. Tunjung is also the name of a Dayak tribe along the Mahakam, whose chiefs had close ties with the dynasty of Kutai (S. C. Knappert, "Beschrijving van de onderafdeeling Koetai," BKI, LVIII [1905], p. 592). "Kotai" or "kutai" is used in Malay for hanging at the end of (a stick, stem or string). We will return to Kutai presently. 
Fa-hsien's deprecating note on Yeh-p'o-ti is the last report we have about the original Yavadvîpa. The flow of trade may have soon moved to the coast of Java. For a long time Yavadvîpa must have been a myth without a definite home, until quite naturally the Javanese kings whose agents had begun to frequent the China water-way after 422 adopted it (and its implications as a trading center) as a new name for the Sabadibai of Ptolemy and the Shê-p'o (Jawa) of the Chinese reports. It is most likely that the name first started moving to the other side of the.Java Sea through the medium of Indian visitors whose confusion increased with the steady advance of Javanese preponderance and the gradual eclipse of the original Yava. The new name may thus have become the fashion in Javanese Brahmanic usage. The first instance of this substitution known to us is the "dvîpavaram Yavâkyam" of the Sanskrit inscription of Canggal (732), which seems determined to show unequivocally that the new Yava was equal to the old one in fertility and gold mines.69 This is followed by a (not completely verified) "Yavâkyapura" in a ninth century Ratu Baka inscription, while at the same time an 01d-Javanese inscription of 865 speaks of "bhumi ri Java."70 Thus in the beginning there may have been a difference in usage between Sanskrit and 01d-Javanese texts; afterwards (especially in the East Javanese period) both Yava and Java were used indiscriminately in both kinds of texts.

It remains to make one more trip inland from the original Yavadvîpa. One degree north of the (according to us) purely hypothetical Thinai and at the extreme eastern border of the Sinai habitat, Ptolemy places an inland town whose name in the manuscripts is fairly unanimously read as Sagara. Sanskrit sagara equals Malay laut (sea). At the southeast corner of Borneo we find a Pulau Laut, and it seems that this corner once also knew a Tanah Laut. ${ }^{11}$ This might once have been a name for the entire east coast. In any case, it is remarkable that in one of the inscriptions of Kutai someone (probably King Mûlawarman) is stated "to be born from Sagara like Bhagiratha."72

This part of Ptolemy's work is rounded off with the statement: "From Katigara to the west the boundary is formed by unknown land surrounding the sea called Prasôdês (the southern part of the Indian Ocean) as far as the cape of Prason, where the Thrakia Sea begins. This stretches as far as Cape Rapton and the south of Azania." The last two items were already known to the author of the Peripious and located on the African coast, probably at Quiloa near Zanzibar and at Hazine or Ajan, south of Ras Hafun. ${ }^{73}$ This crossing is of course not a part of the itinerary of his sources. But Ptolemy like Pliny may have heard rumors about such crossings by Indonesian boatmen.74 How-

69. H. Kern, Verspreide Geschriften, VII, pp. 115-28; Purbatjaraka, Rawajat Indonesia I (Djakarta: Jajasan Pembangunan, 1952), pp. 50-58; J. Ph. Voge1, "Aanteekeningen op de inscriptie van Tjanggal," BKI, C (1941), pp. 146-47. The addition akya (called or so-called) indicates probably only that "yava" is a name. It is, however, tempting to see in it an allusion to the borrowed nature of this name.

70. De Casparis, Selected Inscriptions, pp. 274, 258-60, 311.

71. Ras, Hikajat Bandjar, map. The name is not mentioned in the glossary or in the text.

72. J. Ph. Vogel, "The Yupa Inscriptions of King Mûlavarman from Koetei (East Borneo)," BKI, LXXIV (1918), p. 215.

73. Bunbury, A History, II, pp. 452-53.

74. J. I. Miller, The Spice Trade of the Roman Empire 29 B.C.-A.D. 641 (Oxford: The Clarendon Press, 1969), pp. 153-72; A. Toussaint, History of the Indian Ocean

(Chicago: University of Chicago Press, 1967), pp. 30-31, 36-43. Prasôdês could 
ever, running true to form, he added a personal touch by pouncing on this route and transforming it into a coastline. ${ }^{75}$

V. Ptolemy's Organization of Mainland Southeast Asia

Until now we voyaged mainly by sea, with a few occasional excursions inland for special purposes. The inland data of Ptolemy's geography are of course no less interesting, but for the place names we are missing the guidance of a trade route, whether determined by a coastline or not. In exceptional cases when we havr some point of verification it may be possible as I showed above to reconstruct a few of the numerous place names with some plausibility. A thorough geographical, archeological and linguistic knowledge of the region (which I do not have) may be able to add a certain number of details. But even so, many of these details would necessarily remain problematic. However, apart from the place names, it seems possible to reconstruct the general features of Ptolemy's geography of mainland Southeast Asia with sufficient certainty. Therefore we will confine our efforts to this task.

\section{Mountain Ranges}

In the eighth paragraph of the second chapter of his seventh book Ptolemy starts on an elucidation of the mountain system of Southeast Asia. He first distinguishes two consecutive ranges along the western border of India-beyond-the-Ganges, both running from northwest to southeast. They are called the Bêpuron and the Maiandros. Along the opposite eastern border of the same part of Southeast Asia we find the Dabasa range, running from northeast to southwest. Furthermore there is the Sêmathênon range crossing the northeast corner of the Sinai habitat in a northwest-southeast direction. Finally along the whole northern border runs a series of ranges forming the roof of the whole region beyond-the-Ganges and the floor of Skythiê and Sêrikê. Those are the Imaus or Himalaya and the Sêrikê range.

If we compare this arrangement with the mountain formations on a modern map, it would seem that the most western sequence, the BêpuronMaiandros range, very likely corresponds with the ranges that start from the (modern) India-Burma border, where they center in the Naga Hills, and continue through the Chin Hills and the Arakan Yoma. The name Bêpuron obviously contains the element pura with a Greek ending. The first part could be an allusion to the tribal name Naga, a word that in Sanskrit has the meaning serpent, and thus could be considered synonymous with phani. The compound Phanipura as a reference to the Naga region makes more sense if we remember that this region is contiguous with the district of Manipura (Manipur, jewel country). Though there are no confirming references to Manipur in old-Indian literature, probably because the region was considered a barbarian out-of-the-way

be some unorthodox Greek compound of prassô and hodos, resulting in the notion "through-way."

75. Ptolemy's "fish-eating Ethiopians" are not related to this African venture. It might be interesting to know what the Sanskrit original called them. Probably a name involving nila (black). Ethiopia was for the Greeks the nearest black country and was supposed to comprise the Sudan as well (Bunbury, A History, I, pp. 48,72$)$. 
boundary corner, the parallelism, Phanipura-Manipura, seems too conspicuous to be merely accidental. While Ptolemy does not include districts in his series of inland features, he does mention east of the Ganges a place Maniaina whose name is probably derived from manţyaina, meaning jewe1-1ike sun.

The name Maiandros/Mahendra seems to make sense in this Arakan context, to the east of the Ganges. According to the Râmâyana, a Mahendra mountain was placed at the southern tip of India by Agastya to separate India from the wild country of Râvana. ${ }^{76}$ A Mahendra east of the Ganges would have served the same purpose in Northeast India. However, a more likely reason for the Mahendra toponym here may have been that the oldest contacts of Arakan were with Orissa at the opposite shore of the Gulf of Bengal, and that the Orissa people named these mountains after the Mahendra chain in their own country. The "metropolis" Tôsalê (2.23) at the western foot of the Arakan mountains may be indebted for its name to the same country, the ancient city of Tosali (Dhauli) in the delta of the Mahanadî.77

When determining the location of the second range, the Dabasa, we have to remind ourselves that the enormous upwards surge to the north of the Great Gulf, which we discussed earlier, 78 caused that part of Southeast Asia between the gulf and the northern mountains to be pushed aside or flattened into a distorted image of its true self. Moreover, its configuration had to be adjusted to Ptolemy's world picture and his longitudinal scheme.79 Ptolemy's Dabasa mountains, which stand out to the southwest like a splinted arm, will have to be rotated to the south bringing them in line with, successively, the present-day Shan Hills and Dawna and Bilauktaung ranges. The name Dabasa is phonetically rather characterless, and Ptolemy gives no indication of its meaning. Provisionally, I suggest calling this chain the Pine-resin (Dâru-vâasal) mountains, which is at least a sensible possibility. 80

76. K. A. Nilakanta Sastri, "Agastya," TBG, LXXVI (1936), p. 485; C. Maloney, "The Beginnings of Civilization in South India," Journal of Asian Studies, XXIX $(1969-70)$, p. 605. It was also a "golden" mountain, while the Maiandros lay in the "Chrysê chôra."

77. Ha11, History of Southeast Asia, p. 36 (Orissa influence). The oldest Arakanese inscriptions seem to call their capital city "Vaisali." This might mean a change of allegiance from Tosali to the better known Vaisali in the Ganges plain. See also J. Dowson, A Classical Dictionary of Hindu Mythology and Religion, Geography, History and Literature (London: Kegan Paul, 1928), Mahendra (p. 170).

78. See "Suvarṇadvîpa and the Chrysê Chersonêsos," p. 35.

79. See note 45 .

80. This conjecture is inspired by chapter 7 of Wolters' study (Early Indonesian Commerce, pp. 95ff., esp. pp. 105-8) entitled "The Pine Resin of the Southern Ocean." This resin (ju) was important for the China trade and most of the traders who crossed the above-mentioned ranges were on their way to markets that mediated in this trade. The modern sites producing "merkusii Jungh" on the mainland are the West Tongkin and South Shan States and the Martaban region. At least the latter two are located in the Dabasa chain. Though the ju trees grow fast, during two thousand years of swidden culture they were probably thinned out in many other areas of the mountains. Thus it is conceivable that in times past the Dabasa chain was even more noted for its pine-perfume than it is today. 


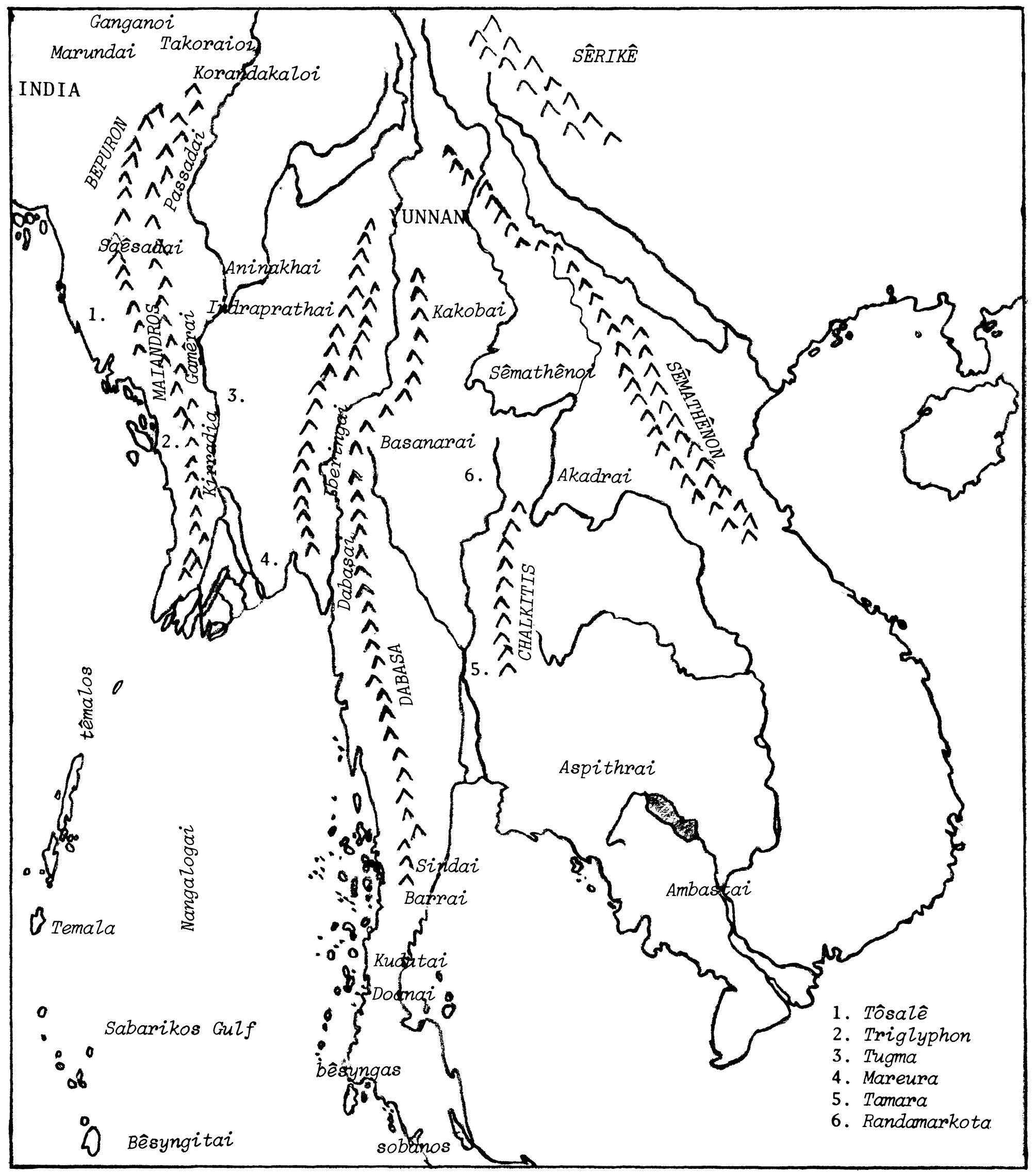

Ptolemy's Organization of Mainland Southeast Asia 
The third range in Ptolemy is the Sêmathênon, whose name we a1ready explained as the Semacaina (the border range belonging to Thina). Both its name and its location seems to place this range in the YunnanLaos border region, with maybe a southern extension into Vietnam. Since Ptolemy's Sêrikê range comes from a different set of sources, it is difficult to define its position in relation to the Sêmathênon. Since the Sêrikê is described as a continuation to the east of the most southern part of the Himalayas, it would seem that in the Sêrikê we have to include the Yunnan massif, enlarged perhaps by its continuation into southeastern China.

The Rivers

Two unnamed tributaries flow from the Bêpuron into the Ganges, while from the Mahendra three rivers (whose mouths are mentioned in Ptolemy's discussion of the coast voyage) flow westward into what is clearly the Bay of Bengal. The arrangement of these rivers corroborates the location we assigned to the Bêpuron and Mahendra ranges. Also, from the southern end of the Mahendra three other rivers are said to originate which Ptolemy calls the Têmalos, the Bêsyngas and the Sôbanos .

It is clear from the first part of our study8I that the Têmalos was no more a river than the Sinos. Rather, it was the "water-way" or customary sea route from somewhere on the Burma coast, probably the market town of Bêrabonna (Meyebon?), directly to Littie Andaman. Its source in the Mahendra was fabricated by Ptolemy (as he created a source for the Aspithras), completing his picture by recruiting the nearest mountain he had knowledge of to be a foster parent. 82 The same has to be said of the Bêsyngas River, which represented the coastal route from Takuapa to Mergui and Martaban. It is no coincidence that, while Ptolemy dotted the whole of mainland Southeast Asia with inland towns, not one town was located between the Bêsyngas and Têmalos Rivers, or between these rivers and most of the Sôbanos River, because that area was nothing other than the northern part of the Andaman Sea. This Sôbanos River, which I earlier proposed to be the Merangin on Sumatra, 83 was another of Ptolemy's problem children. According to his calculations the Sôbanos part of the voyage must have been outside the Chrysê Chersonêsos, so that the river could not be given the benefit of a source in the unnamed mountains that pervaded the Chryse Chersonêsos. Therefore he had to extend the river the length of the Andaman Sea in order to provide some mountains for its source.

81. See "Suvarṇadvîpa and the Chrysê Chersonêsos," p. 10.

82. The only river without a source was the Sinos, because it was supposed to originate in the unknown "southern continent." Also Ptolemy's "unnamed capes" were his inventions, though they could coincide accidentally with a corner or cape if the change of course was necessitated because the voyagers had to round that actual corner of some island or mainland. In cases where Ptolemy's sources reported that they, for example, sailed eastward for one or more days and then changed course to the northeast, the reason could have been that they had to avoid an area of dangerous rocks or wanted to sail before the wind until they were a safe distance from an area of known piratical activity. After clearing these hazards they changed back to their intended course. But for Ptolemy this meant a bend in the coastline, therefore a cape.

83. "Suvarṇadvîpa and the Chrysê Chersonêsos," p. 36. 
The problem of river sources was not all that troubled Ptolemy. For some rivers, he was able to locate the sources in his manuscripts, but not the mouths. Usually these river mouths had been reported to him by his coastal voyage informants, but he was unaware of the connections. On the other hand, in many cases the mouth of a river must have been the only information he possessed about the river, except perhaps the general direction of the location of its source. However, we may assume that among the inland data rivers were also mentioned. For example, it is impossible for the mountains, peoples, towns, and regions of Burma to have been reported without mentioning such rivers as the Chindwin, the Irrawaddy, the Sittang, the Salween or the Tenasserim. However, their mouths were not mentioned, because the south coast of Burma and the west coast of the Malay Peninsula were not included in the coastal voyage. The only conclusion open to Ptolemy, who thought that his itinerary covered the entire coast, was that these rivers emptied into other rivers reaching the coast as one of the mouths reported in his coastal voyage sources. Applying the same principles, he constructed the river system of the Golden Peninsula.

Earlier I identified the mouth of the river Doanas with the Kirirat, a small stream which crosses the Malay Peninsula from Takuapa to the Bay of Ban Don. In Ptolemy's system, however, it becomes an immense river with one branch originating in the eastern slopes of the Bêpuron in north Burma, and another in the eastern side of the Dabasa, probably in the Southern Shan States. United these two branches course southward until they reach the Bay of Ban Don. Though we do not know exactly what rivers were mentioned in Ptolemy's sources, or whether they were given names or simply indicated as "streams," it seems obvious that this super-river represented a fusion of the Chindwin, the Irrawaddy, the Sittang, the Tenasserim and perhaps others. But, this simplification may have been the only way open to Ptolemy in view of the data he had and his aversion to dotted lines or question marks.

Other inland rivers, the Dorias, the Sêros, the Aspithras, the Ambastos, the Sinos, and the Kotiaris received sufficient attention in the course of my discussion of the coastal voyage.

\section{The Peoples}

Starting again in the remote northwest, we find between the Himalayas and the Naga Hills, thus perhaps in the Patkai Hills and around the northern passes, a people whose name does not leave much doubt as to the Indian's opinion of them--the Takoraioi, derived from tarkaraya (behaving like robbers). In the extreme north along the river Sarabos (sarabhasa = impetuous, violent; the river Brahmaputra?) live the Ganganoi. Since these people do not live along the Ganges, their name has probably nothing to do with the name of that river, but is more likely derived from gagana, sky people, dwellers in high altitudes (Tibetans?). According to Pliny, the Marundai lived below the deserts. He calls them Moruni.84 Therefore they may have been the desert-river people (maru-nadî). South of the Takoraioi are located the Korandakaloi. Their name has something to do with basket (karanda). They may have been known as "basket rogues" who silently bartered by leaving

84. Eggermont, "The Murundas," p. 276. 
baskets on trees and cheated (karandakhala), or simply as basket makers (karandâkara). Next come the Passadai (other manuscripts have Passalai). "The name is probably derived from apasada, meaning outcast.

Somewhere in the northern reaches of the Mahendra live the Saêsadai, pygmies, pilose, with broad flat faces and fair skin. Their name may come from nishâda (or more likely sanishâda, nishâda-like), the name given to an. Indian aboriginal tribe (described as fishers, hunters and robbers) or also to a certain despised caste. They are also called Piladai or Tiladai, probably derived from Cilâta, the Pâli equivalent of Kirâta, a name we will meet shortly. ${ }^{85}$ Along the slopes of the same Mahendra are located a tribe of anthropophagi, called the Gamêrai or Tamêrai. Whatever the origin of the name, the people were reputed to be jaminâhâra (people snatchers or kidnappers). Further south along the same slopes we reach the Kirradia region. In Sanskrit kirâta is the name of an aboriginal mountain tribe of hunters in India, also used in the general sense of mountain dwellers (by definition barbarous, of course).86 The only redeeming feature seems to be that the tribe "is said to have the most excellent malabathron."87

Ptolemy is not very definite about the location of his Archyra chôra, a region that "contains most of the silver mines, it is said," nor about the position of the Chrysê chôra, a rich gold-mining area. The latter may have been either above, beyond or past (hyperkeitai) the former. A map of Burma showing the mineral deposits is not very helpful either, because the distribution of silver or gold is not limited to a well defined part of the country. We are told, however, that the population of the Gold Country consisted of the pygmies with flat noses, fair skin and hairy bodies we met above and that the country extended to the habitat of the anthropophagous Bêsyngitai. These people, far from being the inhabitants of Bêsynga (Bahihsimha[1a]), were the plague ( $i t i$ ) of this region. Therefore they must have been the piratical boat people of the islands along the Andaman Sea coast of the Malay Peninsula, the terror of the Bêsyngas water-way, and well known to any sailor who ever visited that part of the world.

Again Ptolemy returns to the north, this time to give us an enumeration of the peoples connected with the Dabasa mountains. To the west of these mountains we meet with (from north to south) the Aninakhai (Aminakai), the Indraprathai, the Iberingai, the Dabasai and the Nangalogai. The habitat of these peoples must have been in the presentday Kachin States, Kaukkwe Hil1s, Shan States and Karen territory. The name of the second tribe could mean that they lived on some Indraplateau or exemplified the characteristics (preferably the less amiable ones) for which the people of Indraprastha, an ancient Indian city in the

85. Ibid., p. 281. Some manuscripts read Bêsadai, which might have been derived from bhîsada, dwelling in fear. But the explanation given above seems to be more in line with the general character of these names and also with the substitute name Kirâta. It is curious though that the Periplous says of these Sêsatai that they are of a "peaceable disposition" (Wheatley, The Golden Khersonese, pp. 130-31). The fact that they live "on the border of the land of the Thinai" seems to indicate that they are dispersed through the whole northern part of mainland Southeast Asia.

86. In this general sense it is used for example by the king of Champa in an inscription of 1149. Coedès, Les États Hinduisés, p. 301.

87. The Greek malabathron is derived from Sanskrit tamala-pattra, leaf of the Tamala tree, a species of cinnamon. 
Kuru region, were perhaps infamous. The Iberingai may have been connected with salt mining (ibyấrina). Only the fifth people have an authenticated name, because Ptolemy adds the translation of their name --world of the naked (Sanskrit nagna-loka). He also notes that their habitat extends to the Mahendra range. This "world" is of course not a tribe, but the general name for the population of the Andaman Sea, extending from the Mahendra range in the north to the Bêsynga range in the south.

To the east of the Dabasa range only two peoples are mentioned. In the far north 1 ive the Kakobai or summit dwellers (Sanskrit kakubh). More to the south is the habitat of the Basanarai (vâsa-nara, aromatics people), who evidently not only collected pine resin like the Dabasai, but also other perfumes. Their homeland must have been in northern Thailand, because progressing to their south is the Chalkitis area, which we already located to the east of the middle course of the Menam. Their center may thus have been the place to which Ptolemy's sources gave the poetical name Ratna-mârakata (the town of the jewel that is emerald-like) because it produced much nard.

Further to the south, we meet the Kudutai, the Barrai, the Sindai and the Daonai. It is evident that we have now entered the Malay Peninsula. The last two names are easily recognized as those of the people of the Sinda settlement and the Ban Don region, mentioned above in our discussion of the coastal voyage. Because of this connection it will be possible to recognize also the heavily mutilated Kudutai as the name for the Kortatai of the Kra region and the still more corrupted Barrai as the name for the Pagrasa (Tenasserim). These peoples are probably of Malay stock, but Ptolemy's names are no help in establishing any ethnic identity (except for the pygmy people). "After these (peoples) comes a hilly region that is contiguous with the land of the Lêistai and which contains only tigers and elephants." Since the Lểistai are the Kubu tribes of South Sumatra, 88 this contiguous country must have been the southern part of the Malay Peninsula

Place Names

In addition to those situated along the coasts, Ptolemy mentions about fifty inland towns, including five capital cities. We discussed a few of these towns earlier. Two of them were the capitals Thinai and Tôsalê. We will here limit out efforts to the three remaining capitals.

First there is Mareura (2.24) which, according to its location on Ptolemy's map, could have been close to the Gulf of Martaban. The most likely derivation of the name seems to be maryâvara. Since mary $\hat{a}$ means landmark, boundary, but also moral law and vara means best, very, this name could well be a synonymous substitute (fairly common in Indian literary usage) for the surname of the old Mon capital Thatön, that is, Sudhammavat $\hat{\imath}$. To the north of Mareura and west of the Mahendra we find a second "royal city" named Triglyphon (2.23). It is curious that a certain number of manuscripts substitute the name Trilingon or add it as a variant name. The translator who made the Greek text evidently forgot to state expressly that the first was the Greek translation of the second, so that most manuscripts rejected the second one as an impossible variant. Both the Greek and the Sanskrit name express the idea "with three carvings" or "with three engraved marks." It is

88. See "Suvarṇadvîpa and the Chrysê Chersonêsos," pp. 37-38. 
difficult to say what was meant by "three marks." In grammatical usage the word trilinga commonly means an adjective that can indicate all three genders. However, it is most probable that here simply the Sivaitic emblem in some triadic form is intended. Probably this city was the "Lin-yang" ( $i \dot{i n g a}$ or plural lingâni) of the Chinese reports. In that case Hall's suggestion that the Chinese name indicated Srikshetra, 89 cannot be sustained because the location of Trilinga is west of the Mahendra mountains. The old capital of Pyu near Prome, known as Srikshetra, has a location that is more in agreement with the location of Ptolemy's Tugma. However, his Sanskrit source must have written t $\hat{u} r a-g m \hat{\alpha}$, rich or abundant earth, an acceptable substitute for Śrikshetra.

Though Ptolemy's Mareura and Tugma are synonymous with the Sanskrit surnames by which those two towns afterwards became known, it does not follow per se that they were substitutes, because we do not know whether the latter names already existed. It may be that both the Ptolemaean and the Sanskrit names go back to the same source, namely some autochthonous name or feature. It is more probable, however, that the second of the three cities in any case already had an established Sanskrit name, if our identification of Lin-yang with linga is correct. We may note also that, since these are the only three capitals known to Ptolemy in this region, one of them was most probably the capital of the kingdom.of Tun-sun. It would seem that in view of its location Mareura (Thatön) is the most likely candidate.

Two Forgotten Islands

In the course of our first paper we suggested locations for the islands mentioned by Ptolemy at the end of his second chapter. However, we failed to discuss two of these islands, Salinê and Bazakata, positioned "a considerable distance north of the Agathou Daimonos Island" (Sumatra). From this location it seems evident that we must look for them in the Andaman Sea. Salinê lay east-southeast of Bazakata and was reportedly abounding in pearl shells. Moreover its people always went naked and "call[ed] themselves (sic!) $\mathrm{Ag}(\mathrm{g})$ inatai." I doubt that these naked pearl fishers were so versed in the sacred language of India that they knew themselves to be nagnata, naked beggars, though the name (had they known it) might have been considered a title of nobility in this "world of the naked."

However, the abundance of pearl shells is the important thing. There is only one place in the Andaman Sea which is known today for its pearls--the Mergui Archipelago, especially Mergui Island. Since the pearl oyster requires a habitat with very special conditions, found only in a few places, it can be destroyed (or nearly so), by human rapacity, but cannot move to another place. It will grow again on the same place if conditions get better. 90 Thus the presumption seems justified that it occupies the same place today as it did nearly two thousand years ago. This presumption seems to find corroboration in the name Salinê. There are as far as I am aware two Sanskrit words

89. Ibid., p. 35.

90. J. E. Spenser, Asia East by South (New York: Wiley, 1957), pp. 98, 103. See also the Han reports about the vanishing of the pearl oysters along the Kwantung coast because of mismanagement by grasping officials, and their return under a better administration (Ying-shih Yü, Trade and Expansion, p. 181). 
from which the name could have been derived: salina, with fixed abode, and samlina, united. The second of these is the exact equivalent of the Maiay mer( $\breve{e}) g u i$ which translates, to form a team, to band together --perhaps for the overland crossing. 91

In view of the direction noted by Ptolemy, Bazakata may have been either Kabosa or Tenasserim Island in the same Mergui group, though their distance apart is much less than that calculated by our author.

VI. Conclusion

The geography of Ptolemy was generally based on material compiled by Greek predecessors. This is only partly true, however, for his geography of Southeast Asia. Though Ptolemy retained (with corrections) the main elements handed down to him by his immediate precursor, Marinus of Tyre, he boasted nevertheless that he possessed considerable new material for this part of the world (I.17.5). This may have been the case especially for the second part of the voyage (after Zabai), for which Marinus' information was apparently very defective. We would of course be most interested in the nature and content of these newer sources. However, Ptolemy does not describe them, nor do any of them seem to have come to us except as part of Ptolemy's opus--that is, they are anonymous and appear in a definitely adapted and assimilated form. Is it still possible to assess their real nature and content?

Ptolemy's adaptive methods have long since been recognized by Ptolemaean scholars, though perhaps they were unaware of the extent of this tendency. Fundamental, of course, was his stubborn attempt to build a quasi-complete geographical system of the "known" earth based on the fragmentary and casual observations of travelers. He was an astronomer bent on counting and measuring. The first consequence was his highly problematic conversion of sailing times into sailing distances in order to be able to construct an all-embracing system of coordinates. Another less noted consequence was his wholesale conversion of sailing routes into coastlines in order to create complete and reliable continents and definite borders for his seas. He could not permit any loose ends to show. His preoccupation with complete river systems is in the same category. In order to reconstruct the original data of his sources we continually had to look out for these tendencies and their possible consequences, while we confronted Ptolemy's outlay with alternative possibilities offered by the real geographical constellation of Southeast Asia and with what we know about the most probable pattern of ancient traffic and trade in the region.

It seems clear from Ptolemy's nomenclature that his sources were composed by literary people, not simple sailors. This does not mean that the names were the product of poetic flights of fantasy. On the contrary, they were real itineraries founded on personal observation or on sufficiently reliable reports. On the other hand they remained true to certain literary standards and conventions, such as the use of synonyms (including Sanskrit synonyms for Malay names), artificial word explanations, allusions and maybe even the omitted syllable game, a frequent feature in not only mythological poetry, but also in royal charters from both India and Indonesia.92 We hope that our study may have

91. The word śalina would more probably have been transliterated as zalinê.

92. On these alamkâra, see A. B. Keith, A History of Sanskrit Literature (London: Oxford University Press, 1956), pp. 379-85, 390-96; J. G. de Casparis, Selected 
contributed to a better understanding of the foundations of Ptolemy's geography and will stimulate fresh lines of inquiry.

Inscriptions, pp. 266-71, 287; C. Hooykaas, "The Paradise on Earth in Lenka," BKI, CXLIV (1958), pp. 288-90.

In view of these literary properties we might wonder (1) whether an original Sanskrit text was composed in verse, while the Greek translation used by Ptolemy gave only a summary; and (2) whether such missing syllables as occur in Balonga, Tugma, and so forth, were always the victims of negligent copyists, or were part of a literary guessing-game (akşar acyutaka).

Errata for "Suvarṇadvîpa and the Chrysê Chersonêsos," Indonesia, No. 18 (October 1974). In the following, the pages refer to these paperback editions:

note 7 Wheeler, Rome. Harmondsworth: Penguin Books.

Cary-Warmington, The Ancient Explorers. Harmondsworth: Penguin Books.

note 34 Collis, Siamese White. The Albatross Library, 1947 (copyright 1947 by The Albatross Ltd., London and Paris; not to be introduced into the British Empire or the U.S.A.).

of the following multi-volume works the pertinent volume is:

note 8 Hennig, Terrae Incognitae. Vol. I.

note 22 Bunbury. Vol. II.

note 56 Von Humboldt. Vol. I, p. 61.

note 80 Geographical Handbook. Vol. I.

note 130 Encyclopedie. Vol. III. 